\title{
Chain and network science: A research framework
}

\author{
S.W.F. (Onno) Omta, Jacques H. Trienekens and George Beers \\ Wageningen University and Research Centre
}

\section{Abstract}

In this first article of the Journal on Chain and Network Science the base-line is set for a discussion on contents and scope of chain and network theory. Chain and network research is clustered into four main 'streams': Network theory, social capital theory, supply chain management and business economics and organizational theory. Furthermore a research agenda is formulated. The article ends with management implications of the different contributions to this first issue.

\section{Perspectives on chain and network science}

The fast development of technology, combined with increased global competition and more stringent customer demands put strong pressures on companies to improve the quality of their products and processes. Competition involves not only on price, but also a wide variety of product and service attributes. The pressure to do more with less inexorably forces companies to focus on few, unique, hard to imitate and distinctive core competencies, while establishing co-operations in fields in which they do not posses distinctive competencies. For instance, over 50\% of Du Pont's new agricultural product leads stem from university laboratories (MacLachlan, 1995). As Gambardella (1992) concludes: 'To be part of a network, and to be able to effectively exploit the information that circulates in the network, has become even more valuable than being able to generate new knowledge autonomously.' The capability of building and maintaining inter-organisational network relationships is increasingly viewed as key to sustained competitive advantage.

Figure 1 clearly shows that related industrial networks are increasingly converging. The boundaries of the computer industry overlap with telecommunications, office equipment, entertainment and consumer electronics. Increasing interdependence of previously separate industries produces new competitors, but also new possibilities for alliances and acquisitions. Managers may find that control

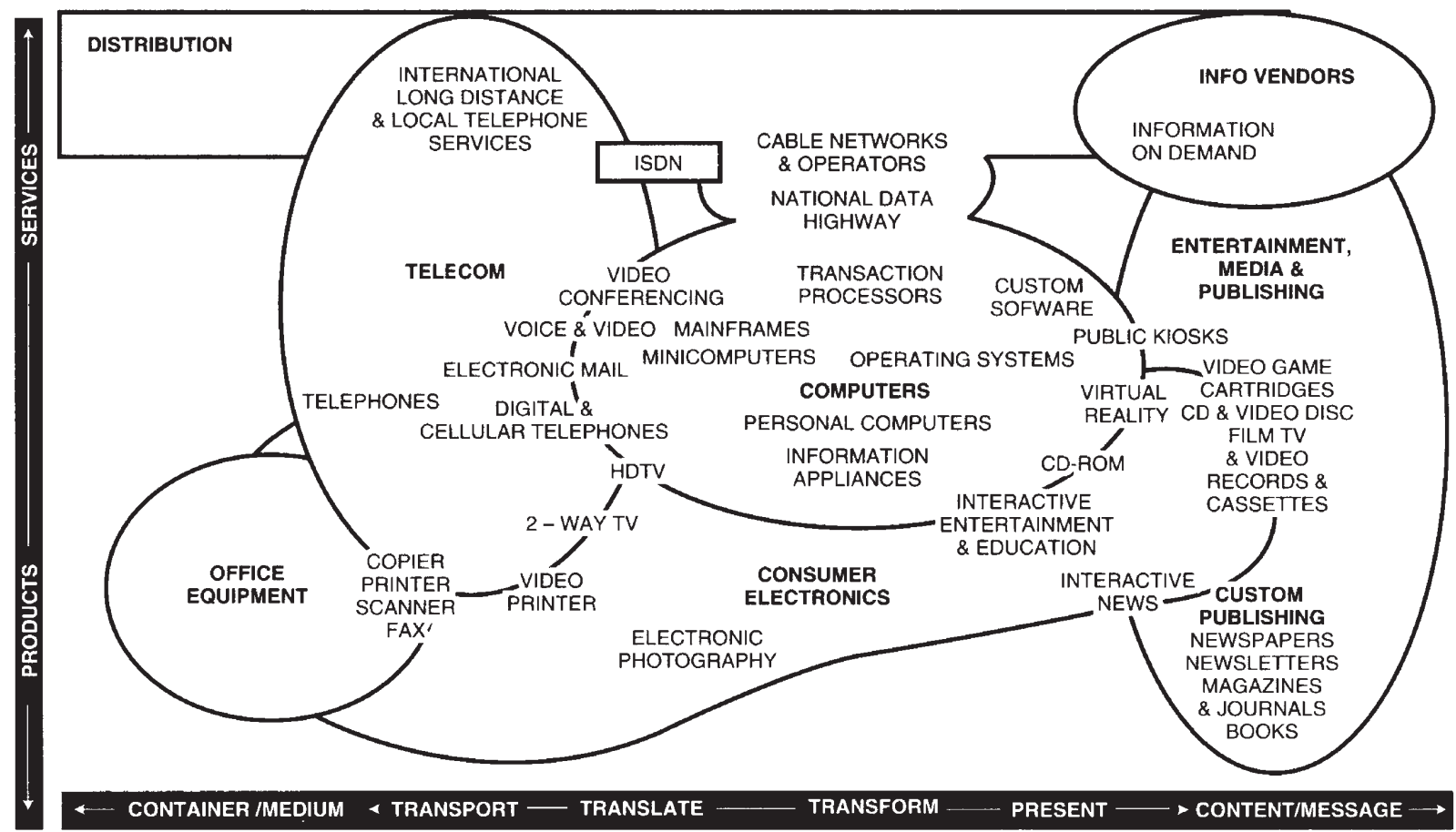

Figure 1: Integration of related industrial networks (Ford and Saren 2001). 
should be shared. As Ford and Saren (2001) cite: 'Today the watchword is not divide and conquer but co-operate-to-compete'. In this emerging competitive environment, the ultimate success of the single business will depend on the management's ability to integrate the company's intricate network of business relationships with outside companies. Several authors refer to such networks as virtual corporations, in which a number of firms create flexible linkages to attain common or complementary objectives (e.g., Davidow and Malone 1992, Campbell 1996, Upton and McAfee 1996, Yoshino and Srinivasa Rangan 1995).

The Journal of Chain and Network Science (JCNS) aims to become the expertise platform for academia and business in this exiting field of research by focusing on the development and validation of strategies, methods and techniques for the improvement of the efficacy of business networks. The concepts addressed in JCNS embrace, among others, chain and network organization and optimisation, partnership management, network dynamics, E-commerce, quality, tracking and tracing and sustainable development. JCNS contributions are based on empirical research, wellconsidered observations of inter-organisational management experience, as well as conceptual contributions to the field of chain and network science. JCNS intends to provide a specific platform for theoretical contributions. The theoretical domain includes new insights from management and organization, sociology, economy, operations research and logistics, and engineering. Each discipline has a different view and method of dealing with inter-organisational relationships. JCNS expects to be truly international. The contributions will reflect the views of scientists and practitioners from all over the world, and will present research results from chains and networks in quite different cultural contexts. In this first issue articles are included that present research findings from South and North America, Canada, the EU, and New Zealand.

\section{Theoretical domain}

Chains and networks are the obvious objects of study in the JCNS. Networks are looked upon as the total of actors within one industry and/or between related industries, which can potentially work together to add value to customers. Actors can be distinguished, either at the micro-level, where the actor is a person, for instance the individual producer, an entrepreneur etc., or at meso-level, where actors are aggregations of individuals working together for a common goal, e.g. firms, research institutes, and government agencies. Chains are considered to be composed of the actors in these networks which vertically work together to add value to customers. A chain is defined as the processes linking supplier and user companies, from the initial raw materials to the ultimate consumption of the finished product.

The concept of the supply network, introduced by Harland (1999, see figure 2), tries to integrate the network and supply chain approach. She looks upon the individual firm as a nexus with its own unique network of upstream and downstream partners. She cites Benetton and Toyota as the best examples of 'hubs', facilitating and coordinating the flow of information in large supply networks, and connecting upstream with downstream demand. A supply chain can be considered to be a special form of a supply network, in which the inter-organisational relationships between the upstream and downstream partners with the focal firm are of a dyadic form. Supply networks differ in shape, reflected in the breadth and length of the network. The breadth of the network reflects the number of suppliers and customers. The length of the network reflects the number of echelons until the end-user. In general, the breadth of the supply network is now narrowed, because of the transition to a limited number of 'preferred suppliers'.

So far, chains and networks have been studied from a wide range of theoretical perspectives, for instance systems thinking, cybernetics, resource dependency approach, transaction cost economics, agency theory and game theory. In order to reach some clarity, we have clustered network research into four main 'streams'. The reader should keep in mind that the overview given below is certainly not exhaustive, but merely gives an impression of the richness of approaches to inter-organisational co-operation.

\section{Network theory}

One of the main contributions of the Industrial Marketing and Purchasing Group (IMP) on network research is the actor, resource, and activity model (Håkansson 1982, 1992). The necessity for organizations to exchange resources is an important explaining factor for inter-organisational relationships in this approach. Activities of actors occur in the form of chains of activities (R\&D, marketing, design, sales, administration etc. combined to value chains, Porter 1985), constituting buyer-seller relationships and industrial networks as these are linked to other actors in the network. In the network theory, forms of collaboration are not only based on economic motivations; power and trust are key concepts in this approach (Uzzi, 1997). Actors are believed to act on the basis of their functional role in the network, while goal orientation, interests, rules and power relations determine this role (Nooteboom, 1996; Omta and Van Rossum, 1999). Kamann (1998) states that, based on the resource-dependence perspective, one can easily argue that neither buyers nor suppliers are completely free to select and change counterparts. The degree of dependency of an 
actor on its counterparts is contingent upon the criticality of the resources supplied (Chatterji, 1996), Power balances play a significant role, and game theory can be helpful in describing the individual actor's dilemma. The actors in these networks will search for alliances, because of the concentration on the 'distinctive capabilities'. Some of these relationships will be based on trust and loyalty, while others will be based on opportunism. A key factor is the innovative process that takes place over time in which actors are able to adjust and interweave transaction chains, accommodate routines that were strange before, transfer activities to other actors and build up common recipes, standards and cognitive maps. In the course of this process the network becomes either sustainable, growth and learning, or it stagnates, or even collapses. The great number of strategic issues that can be addressed within the network approach demonstrates its broad scope. Thorelli (1986) gives a few examples: positioning of the firm and its product, marketing channels and franchising, patent and trademark licensing, turnkey contracts and 'systems' selling, barter and reciprocal trading, make-lease-or-buy decisions, split versus unified sourcing, cartels, and interlocking directorates.

\section{Social capital theory}

Recently, social capital theory has become an important new branch within the network approach. The social capital argument assumes that the behaviour and expectations of actors are constrained by the degree to which the relationship between the actors is embedded in the network structure. Consequently, one may distinguish between a situation in which the network structure is closely knit (the relationships are then redundant, i.e. actor $\mathrm{A}$ has relationships with actors $\mathrm{B}$ and $\mathrm{C}$, and $\mathrm{B}$ and $\mathrm{C}$ also have a relationship) and a situation in which non-redundant relationships prevail. Coleman (1988) describes this phenomenon as the degree of 'closure' of the network. In a similar vein, Granovetter (1985) speaks about strong versus weak ties in a network. Burt (1997) formulates it slightly differently as the occurrence of 'structural holes' in the network. Network-relations may enhance the 'social capital' of a company, by making it feasible to get easier access to information, technical know-how and financial support. But, at the same time, these relationships may lead to 'social liability', e.g. by reducing the possibilities to relate to companies outside the network, risking spillover, and high co-ordination costs of the network-relations. Leenders and Gabbay (1999) provide an extensive overview of the social capital research to date.

\section{Supply chain management}

Supply chain management aims at the integration of business planning and balancing supply and demand across the entire supply chain. It tries to bring suppliers and customers together in one concurrent business process. It spans the entire chain from initial source to the ultimate

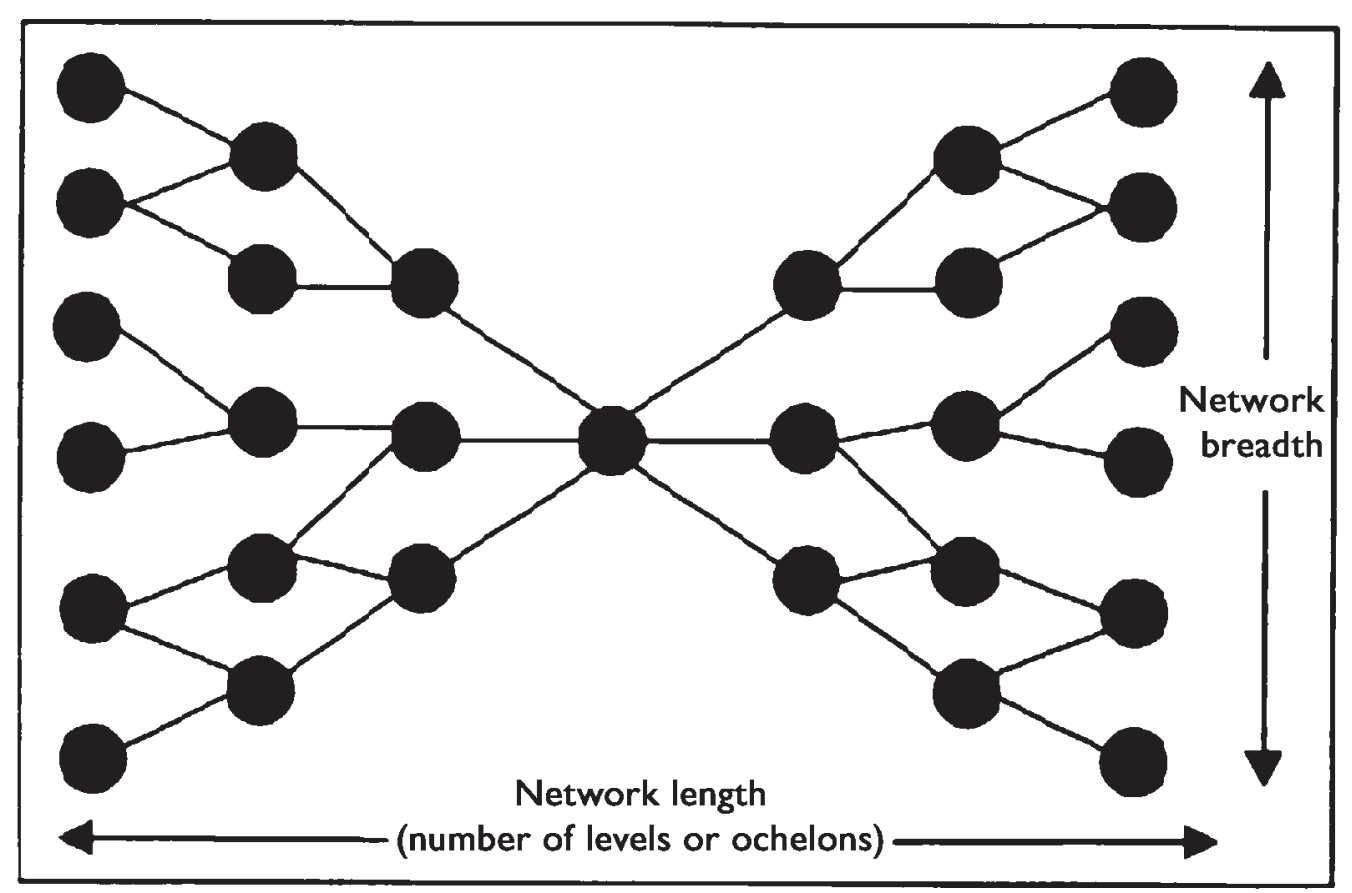

Figure 2: A supply network, a focal firm with its network of upstream and downstream partners (Harland 2000). 
consumer (Schorr, 1998; Handfield and Nichols, 1999; Croom et all, 2000; Tan 2001). Advanced ICT (e.g. Ecommerce) systems are increasingly becoming the backbone of these integrated supply chains. Supply chain management research is well supported by modelling and modelling tools. For example, mathematical models to support decision making for chain multi-echelon replenishment environments are described by Silver et al. (1998). Berry and Towill (1992), and Towill (1996) stress the importance of dynamic modelling in supply chain analysis and design. Handfield and Nichols (1999) deal with dynamic choice problems incorporating optimal control theory. Typical features of supply chain management are (Cooper et al. 1997, Lambert and Cooper 2000) as follows:

- It evolves through several stages of increasing intra- and inter-organisational integration and coordination.

- It potentially involves many independent organizations, thus, managing intra- and inter-organisational relationships is of essential importance.

- It includes the bi-directional flow of products (materials and services) and information, and the associated managerial and operational activities.

- It seeks to fulfil the goals of providing high customer value with an appropriate use of resources, and building competitive chain advantages.

\section{Business economics and organizational theory}

Early work on supply chain management identified logistics benefits of reduced lead times and costs through integrating the internal chain, and through make-or-buy decisions that determine which activities will be vertically integrated and which will be produced through transactions with other firms. The new institutional theory of transaction cost economics (Williamson, 1975, 1985) and agency theory (Eisenhardt, 1989b) provide the rationale for the make-orbuy decisions. These theories are concerned with the governance relationships of organizational co-operation, integrating views from business economics and organizational theory. In TCE the transactions between companies are the units of analysis. The three major characteristics of transactions are frequency of the transaction, uncertainty in the transaction, and asset specificity of the transaction. Agency theory is directed at the ubiquitous agency relationship, in which one party (the principal) delegates work to another (the agent), who performs that work. It focuses on risk assessment and the contractual arrangements between organizations, under conditions of bounded rationality and opportunism. A major point of attention is the trade-off between the cost of measuring behaviour and the cost of measuring outcome and transferring risk to the agent.

\section{The research agenda}

According to Lambert and Cooper (2000), business managers are increasingly aware of the emerging paradigm of inter-network competition. Executives are striving to interpret the company's chain and network structure. To assist them, there is a clear need for building theory and developing tools and methods for successful CNS practice. Below an overview is given of the relevant research questions, inspired by Lambert and Cooper:

- What are the operational definitions of the key business processes and what are the relationships among these processes? How do you obtain buy-in from the functional areas in order to implement a process approach within the firm? Beyond internal integration, how should interorganisational change management be implemented?

- How should chains and networks be mapped? What processes should be used to map the best chain and network structure given the desired outputs?

- What are the methods that should be used to determine the value proposition at the consumer level? How should the various firms in chains and networks share the costs and the benefits?

- What metrics should be used to evaluate the performance of chains and networks and inter-enterprise relationships?

- What are the critical success factors and barriers in linking a firm to specific companies in chains and (industrial) networks?

- How should the firm decide which internal processes to link with these companies? What decision criteria determine whose internal business processes prevail across all or part of chains and networks?

- What determines the type and level of integration that should be applied to each process-link?

- What are the policy scenarios for a company concerning the diffusion and adoption of innovations?

- How does coalition formation take place in industrial networks?

- How can companies join forces in product and process development?

\section{Research methods}

The research presented in JCNS is conceptual or quantitative in nature. It includes descriptive research on chain and network structures and the determination of (institutional, technological etc.) performance factors, modelling with respect to chain and network behaviour, as well as testing the research outcomes on the basis of longitudinal data, including network information (e.g. of strategic alliances). Frequently used research methods include questionnaire surveys (using multivariate statistical methods), simulations 
and case observations. Emphasis is put on the quantification of chain results and empirical testing of model outcomes. Although case studies are generally supposed to provide only limited general knowledge, if carefully designed (e.g. following Eisenhardt 1989a, and Yin 1994), they possess significant descriptive, explorative and even explanatory power. The articles of Lazzarini et al. and Lefebvre et al. in this Journal are fine examples of conceptual contributions, elucidated by a number of carefully chosen case studies. The study of Lindgreen shows the strength of the case study, being its high resolution. In his contribution, the six dimensions of relationship quality are analyzed in great detail. The contribution of Van Heck shows the advantages of the simulation technique, by comparing the effectiveness of competitive auction systems for E-business. The contribution of Cabral and Traill is a fine example of the explanatory power of a large-scale survey. The statistical power of their study is high, even small differences in the study population are traced.

\section{Management implications}

JCNS intends to be a virtual platform in which chain and network scientists meet with business managers to exchange the latest ideas and concepts. Therefore an overview of the managerial implications of the different contributions in the first issue is given below.

In the second article of this issue, Integrating supply chain and network analyses: The study of netchains, Lazzarini et al. try to conceptually integrate the formerly separate research areas of chain and network science. They stress that where the supply chain literature emphasizes the active role of management in inter-organisational collaboration to coordinate the flow of products, information and decisions in supply chains, the network analysis literature tends to portray inter-organisational collaboration as more autonomous and emergent. It advocates managers develop network ties between firms, and at the same time pursue enough flexibility to position their firms to benefit from new information and knowledge in the network. From the point of view of netchain analysis, both types of business policy recommendations are valid depending on the type of inter-organisational interdependence they are addressing. The authors posit that source of value and co-ordination mechanisms correspond to particular and distinct types of interdependencies: pooled, sequential, and reciprocal. The authors therefore argue that it is crucial that management should first carefully analyze the (types of) interdependencies for the formulation of an interorganisational strategy.

In the third article of this issue, An E-commerce transition model for supply chain management, Lefebvre et al. provide a powerful management tool for traditional "brick-andmortar" companies to adapt their procurement, sales and chain management processes to the digital economy, in order to become "brick-and-click" companies. They present a conceptual framework of E-commerce that helps companies understand the requirements needed to move forward towards the seamless integration of intra- and interorganisational processes using a five-wave transition model, which is illustrated through a technology function matrix identifying different functional processes and their evolution over the waves. This five-wave transitional model can accompany key decision-makers through progressive steps that correspond to different B-2-B E-commerce needs and specifications.

In the fourth article of this issue, Determinants of a firm's likelihood to innovate and intensity of innovations in the Brazilian food industry, Cabral and Traill show the vital importance of external alliances in innovation. Their findings confirm that the number of a firm's external alliances, along with its investment in external technology and $\mathrm{R} \& \mathrm{D}$, and firm size are the significant variables in determining a firm's likelihood to innovate. Whereas external alliances, along with firm size and market orientation are related to the intensity of innovation. They conclude that firms might be more effective with a strategy that boosters linkages with other firms, universities and research agencies. Their results suggest that public policy should focus on the stimulation of development and diffusion of pervasive technologies, either directly, e.g. through the financing of research institutions, or indirectly, e.g. through the elimination of institutional barriers, such as the customs barriers to import technology.

In the fifth article of this issue, In search of relationship quality, customer retention and shareholder value: Findings from an exploratory, qualitative multiple case study, Lindgreen warns against the current over-emphasis on the importance of CRM (customer relationship management) in management literature. He argues that these computer-based systems can never replace real interest in customers. He concludes that companies should nourish the quality of the network of relationships with their own employees, their suppliers and customers. But he also warns against over-embeddedness of the network, when the relationships become so tight that it becomes difficult to distinguish between business relationships and friendships.

The last article of this issue, Innovative Electronic Auctions in Supply and Demand Chains: Empirical Research in the Flower Industry, is a fine example of the possibilities of experimental economic research. According to Van Heck, the Internet gradually evolved to a powerful and reliable infrastructure for E-business. Important savings are made as a result of reducing transaction costs, and improving the search-andfind capabilities for all parties concerned. At the moment 
there are many web-based auctions, but the place to study efficient auction systems is not the World Wide Web, but rather the flower auctions in Holland. This is illustrated by presenting the results of a cross-case analysis of ICT initiatives in the Dutch flower auctions. It results in a useful guide to evaluate and explain the successes and failures of ICT-based auctions in new markets.

\section{References}

Berry, D. and D.R. Towill 1992, Material flow in Electronic Product Based Supply Chains. International Journal of Logistics Management, Vol. 3, No 2, pp. 77 - 94.

Burt, R.S. 1997, The Contingent Value of Social Capital, Administrative Science Quarterly, Vol. 42, pp. 339 - 365.

Campbell A. 1996, The Agile Enterprise: Assessing the Technology Management Issues, Proceedings of the 6th International Forum on Technology Management, pp. 197-211.

Chatterji, D. 1996, Accessing External Sources of Technology, Research.Technology Management, Vol. 39, No. 2, pp. 48-56.

Coleman, J.S. 1988, Social Capital in the Creation of Human Capital, American Journal of Sociology, Vol. 94, pp. S95-S120.

Cooper, M.C., D.M. Lambert and J.D. Pagh 1997, Supply Chain Management: More Than a New Name for Logistics, International Journal of Logistics Management, Vol. 8, No. 1, pp 1-14.

Croom C., P. Romano and M. Giannakis 2000, Supply Chain Management: An Analytical Framework for Critical Literature Review, European Journal of Purchasing \& Supply Management, Vol.. 6 pp. 67-83.

Davidow, W.H. and M.S. Malone 1992, The Virtual Co-operation: Structuring and Revitalising the Co-operation for the 21st Century, HarperBusiness, New York.

Eisenhardt, K.M. 1989a, Building Theories from Case Study Research, Academy of Management Review, Vol. 14, No. 4, pp. 532-550.

Eisenhardt, K.M. 1989b, Agency Theory: an assessment and review, Academy of Management Review, Vol. 14, No. 1, pp 57-74.

Ford, D. and M. Saren 2001, Managing and Marketing Technology, Thomson Learning, London.

Gambardella, A. 1992, Competitive Advantages from In-house Scientific Research. The US Pharmaceutical Industry in the 1980s, Research Policy, Vol. 21, pp. 391-407.

Granovetter, M. 1985, Economic Action and Social Structure: The Problem of Embeddedness, American Journal of Sociology, Vol.91, pp. 481 - 510.

Håkansson, H. 1982, International Marketing and Purchasing of Industrial Goods, John Wiley \& Sons, Chichester.

Håkansson, H. 1992, Evolution Processes in Industrial networks, Industrial Networks, Routledge, London, pp.129-143.

Harland, C. 1999, Supply Network Strategy and Social capital. In Corporate Social Capital and Liability, Kluwer Academic Publishers, Boston, pp. 409-431.
Harland, 2000, Corporate Social Capital and Liability.

Handfield, R.B. and E.L. Nichols 1999, Introduction to Supply Chain Management, Prentice Hall, New Jersey

Kamann, D.J.F. 1998, Modelling Networks: a Long Way to Go, Tijdschrift voor Economische en Sociale Geografie, Vol. 68, No. 3, pp. 279-297.

Lambert, D.M. and M.C. Cooper 2000, Issues in Supply Chain Management, Industrial Marketing Management, Vol. 29, pp. 65-83.

Leenders, R.Th.A.J. and S.M. Gabbay (Eds.) 1999, Corporate Social Capital and Liability, Kluwer Academic Publishers, Boston.

MacLachlan, A. 1995, Trusting Outsiders to do your Research: How does Industry Learn to do it? Research.Technology Management, Vol. 38, No. 6, pp. 48-53.

Nooteboom, B. 1996, Trust, Opportunism and Governance: A Process and Control Model, Organization studies, Vol. 17, No. 6, pp. 985-1010.

Omta, S.W.F. and W. van Rossum 1999, The Management of Social Capital in R\&D Collaborations, In Corporate Social Capital and Liability, Kluwer Academic Publishers, Boston, pp. 356-376.

Porter, M.E. 1985, Competitive advantage, Free press, New York. Schorr, J.E. 1998, Purchasing in the 21st Century: A Guide to Stateof-Art Techniques and Strategies, Wiley, New York.

Silver E.A., D.F. Pyke and R. Peterson 1998, Inventory Management and Production Planning and Scheduling, John Wiley \& Sons, Chichester.

Tan, K.C. 2001, A Framework of Supply Chain Management Literature, European Journal of Purchasing \& Supply Management, Vol.. 7 pp. 39-48.

Thorelli, H.B. 1986, Networks: between Markets and Hierarchies, Strategic Management Journal, Vol. 7, pp. 37-51.

Towill, D.R. 1996, Industrial Dynamic Modeling of Supply Chains, International Journal of Physical Distribution and Logistics Management, Vol. 26, No. 2, pp. 23-42.

Upton, D.M. and A. McAfee 1996, The Real Virtual Factory, Harvard Business Review, July-August.

Uzzi, B. 1997, Social Structure and Competition in Interfirm Networks: the Paradox of Embeddedness, Administrative Science Quarterly, Vol. 42, pp 35-67.

Williamson, O.E. 1975, Markets and Hierarchies; Analysis of Antitrust Implications, The Free press, New York.

Williamson, O.E. 1985, The Economic Institutions of Capitalism: Firms, Markets, Relational Contracting, Free Press, New York.

Yin, R.K. 1994, Case Study Research: Design and Methods, 2nd edition, Sage Publications, Thousand Oaks, California.

Yoshino, M.Y. and U. Srinivasa Rangan 1995, Strategic Alliances. An Entrepreneurial Approach to Globalization, HBS Press, Boston 